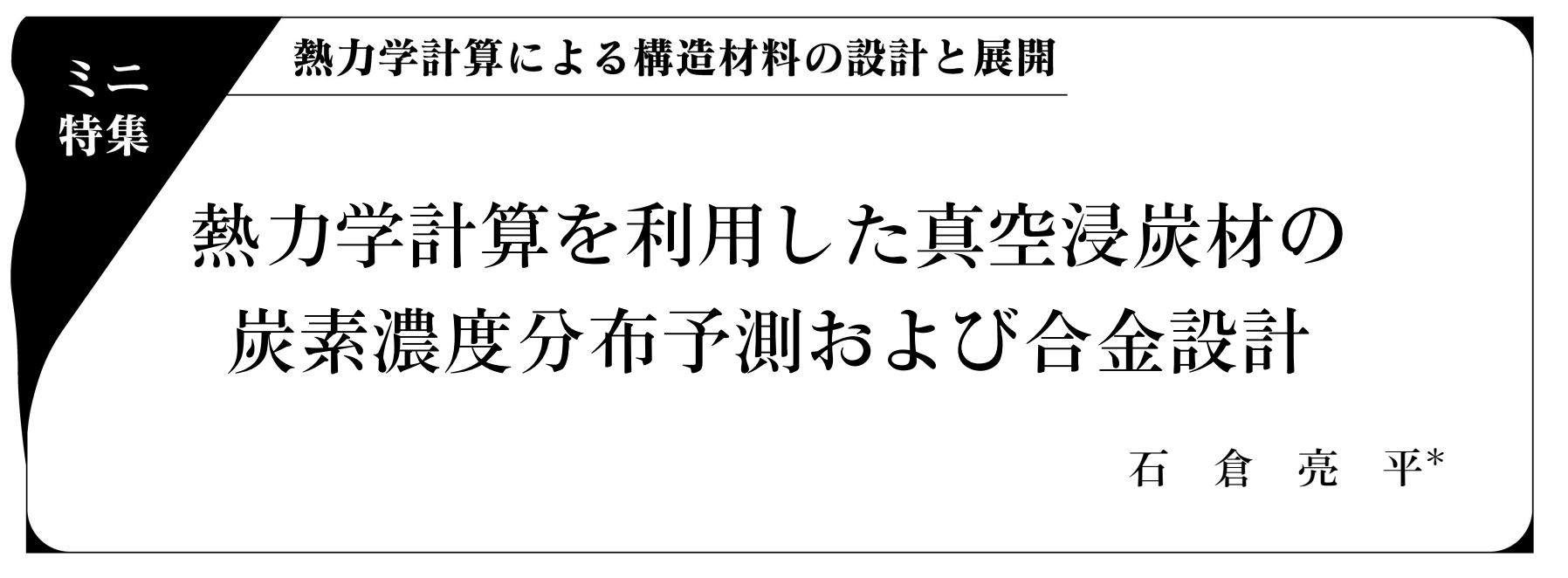

1. はじめに

浸炭焼入れは代表的な鋼の表面処理方法として, 自動車用 の歯車やシャフト等, 高い疲労強度・耐摩耗性が必要とされ る動力伝達部品に幅広く適用されている. 近年, 環境対策, コスト削減, 高性能化等を目的として, 従来の変成ガスを用 い，ブードア平衡反応を利用して鋼中に炭素を侵入させる， いわゆるガス浸炭法に代わり，500～2000 Pa 程度の炭化水 素ガスを炭素の供給源とする真空浸炭法の実用化が加速して いる. 真空浸炭の長所として, 操業中の $\mathrm{CO}_{2}$ 排出量が少な い，浸炭時間が短くランニングコストが安い，粒界酸化がな く高強度な品質を得ることができる等が挙げられる(1)-(4).

一方, 真空浸炭には以下 2 点の短所があったため, 真空 浸炭普及への障壁となっていた. 1点目として，これまで真 空浸炭の浸炭機構が不明(5)-(7) であったことから, 真空浸炭 の条件は経験や勘に基づいて行わ饥ることが多く, 鋼材成分 や部品形状が変化した場合にはあらためて条件を見直す必要 があった. 2 点目として, 実部品において真空浸炭では表面 炭素濃度が形状の影響を受け, 歯車の歯端などのエッジ部の 表面炭素濃度は平面部と比べて高くなることが知られてお り ${ }^{(8)}$, 過度な残留オーステナイトの生成, 粒界への網目状炭 化物の析出(以後, エッジ部の過剩浸炭の生成と称す)により 疲労強度が低下するという問題があった。

これらの真空浸炭の本格的な普及への課題を解決するため には，真空浸炭中の鋼材表面の状態と炭素濃度侵入の機構抒 よびエッジ部の過剩浸炭生成機構の解明が必要不可欠である.

本稿では, 当社に扔いて解明した真空浸炭機構の概要につ いて説明するとともに，真空浸炭の機構と熱力学計算に基づ いて構築した真空浸炭材の炭素濃度分布予測技術ならびに真 空浸炭材の合金設計について解説する.

\section{2. 真空浸炭中の炭素侵入機構}

真空浸炭では, 炭化水素ガス雾囲気中に保持し炭素を侵入 させる浸炭期と, 真空にして炭素を鋼材内部へ拡散させる拡 散期に分かれる. そのため, 真空浸炭中の炭素侵入機構を理 解するためには, (1)浸炭中の鋼材表面の反応と(2)炭素の鋼材 内部の拡散について, 処理温度や鋼材成分・組織の影響を考 慮して検討する必要がある. 本章では, 真空浸炭中の炭素侵 入機構をはじめ, 熱力学計算を活用して確立した炭素濃度分 布の予測に関する研究成果について述べる.

\section{（1）浸炭期の表面炭素濃度と炭化物量}

まず，上述の(1浸炭中の鋼材表面の反応について述べる. 前章にも述べたとおり, 真空浸炭後の鋼材の表面炭素濃度や 析出炭化物ついては種々の説(5)-(7)があり, 処理温度や鋼材 成分の影響も不明であったため, 真空浸炭中の鋼材の表面炭 素濃度を予測することが困難であった。しかし, 当社の研 究(9)(10)により, $\mathrm{Si}, \mathrm{Cr}$ を変化させた鋼種で浸炭層表面を模 擬するために用いた厚さ $0.1 \mathrm{~mm}$ の薄板による実験と熱力学 計算の結果から真空浸炭の浸炭期に抢ける表面の炭素濃度と 炭化物量を決定する機構を以下のと打り解明している.

図 1 亿熱力学計算ソフト Thermo-Calc を用い, データベ ースとしてSGTE Solution Database ver.2を用いて計算し た各成分の $\mathrm{Fe}-\mathrm{C}$ 系状態図(図中のは各温度での黒鉛が析 出する炭素濃度の計算值を, $\triangle$ は浸炭を行った薄板の実測值 を表す)を, 図 2 に厚さ $0.1 \mathrm{~mm}$ の薄板への真空浸炭処理材 および黒鉛を密着させた状態での真空熱处理材の組織観察 (写真右下の数字は炭化物面積率の実測値) を示す. 図 1,2 のと抢り, 黒鉛との平衡を仮定した熱力学計算による表面炭 素濃度の值と実測值はほぼ一致しており, 真空浸炭材の組織 と黒鉛と接触させた状態での真空熱処理材の組織も一致して いる.このことから, 鋼材表面は浸炭ガス(炭化水素)の分解 により生成した黒鉛との局所平衡が成立していると結論づけ

* 大同特殊鋼株式会社 技術開発研究所 構造材料第一研究室; 室長 (干457-8545 名古屋市南区大同町 2-30)

Prediction of Carbon Profiles and Alloy Design in Vacuum Carburizing Steels Based on Thermodynamic Calculation; Ryohei Ishikura (Automotive Steel Research Sect. No.1, Corporate Research \& Development Center, Daido Steel Co., Ltd., Nagoya)

Keywords: low alloy steels, case hardening steels, vacuum-carburizing, carburizing mechanism, prediction of carbon profiles, edge over carburizing, fatigue strength

2018年 5 月 7 日受理[doi: $10.2320 /$ materia.57.439] 
(a) $1.8 \mathrm{Si}-0.5 \mathrm{Cr}$

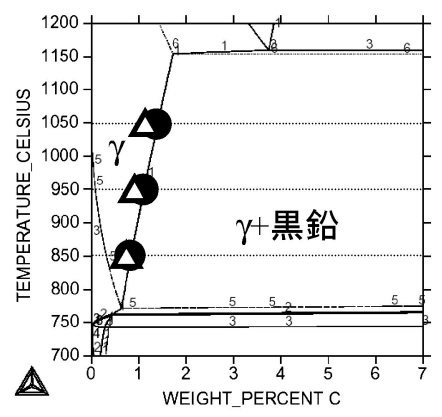

(b) $0.2 \mathrm{Si}-1.0 \mathrm{Cr}$ (JIS SCr420)

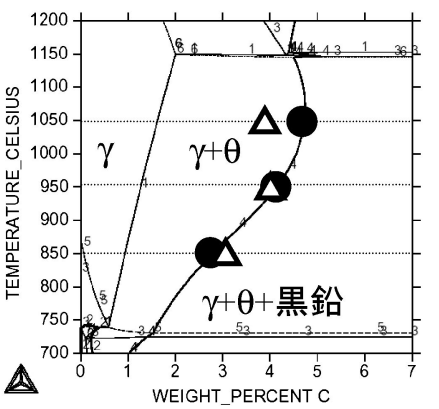

(c) $<0.01 \mathrm{Si}-4.9 \mathrm{Cr}$

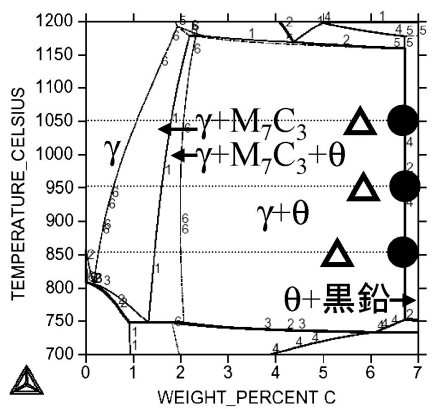

図 1 Fe-C 系状態図による表面炭素濃度の計算值と実測値.

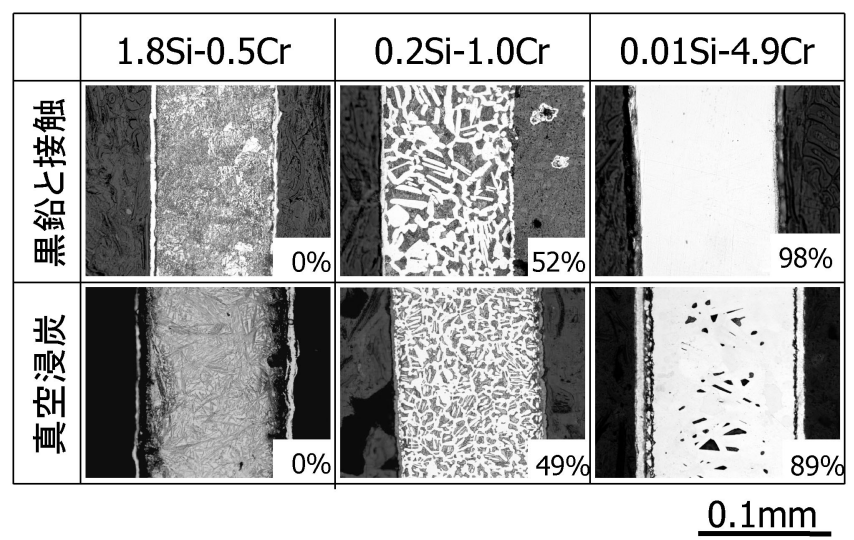

図 2 各鋼種の黒鉛に接触させた状態の真空熱処理材と 真空浸炭材の組織比較.

られる。また, 鋼材成分によって表面の炭化物量は 0 約 100\%まで変化することから, 表面炭素濃度や炭化物量は鋼 材成分の影響を受けることを意味し，炭化物生成元素である $\mathrm{Cr}, \mathrm{Mo}$ の添加とともに上昇し，炭化物生成阻害元素である $\mathrm{Si}, \mathrm{Ni}$ の添加とともに減少する.

これらの成果により，浸炭期の鋼材表面が黒鉛と平衡する 状態にあるものとすることで, 表面炭素濃度や炭化物量は鋼 材成分と浸炭温度から熱力学的に求めることが可能となった.

\section{（2）炭素濃度分布の予測}

次に，上述の(2)炭素の鋼材内部の拡散について述べる. $2 \cdot(1)$ 節で紹介した知見を応用し, 浸炭・拡散後の炭素濃度 分布に与える浸炭条件および鋼材成分の影響について検討す ることで, 炭素濃度分布を予測するシミュレーションを確立 している(9)(11).

炭素濃度分布に及ぼす鋼材成分の影響は，浸炭期の鋼材表 面の炭化物生成量を变化させ, 拡散期での炭化物の溶解に伴 う炭素供給量を変化させることによるものである。つまり, 浸炭期に生成した炭化物は拡散後の炭素濃度分布に影響を与 えることを意味する.このことから, 炭素濃度分布は, 浸炭 期の表面が黒鉛と平衡する状態にあるものとし, 炭化物の存 在を考慮して拡散方程式を解くことで精度よく予測できるこ とを明らかにした（図 3)。詳しい計算方法とその過程につい ては参考文献 (9)を敃読みいただきたい.

以上のことから, 鋼材成分, 浸炭条件 (処理温度, 浸炭時 間，拡散時間）抢よび次章で解説する部品形状の情報があれ ば，平面ならびにエッジ部の炭素濃度分布を精度よく予測可 能であり，この予測シミュレーション手法を用いることで客 先の要求に対して鋼材成分や処理条件の設計提案が容易にな った.

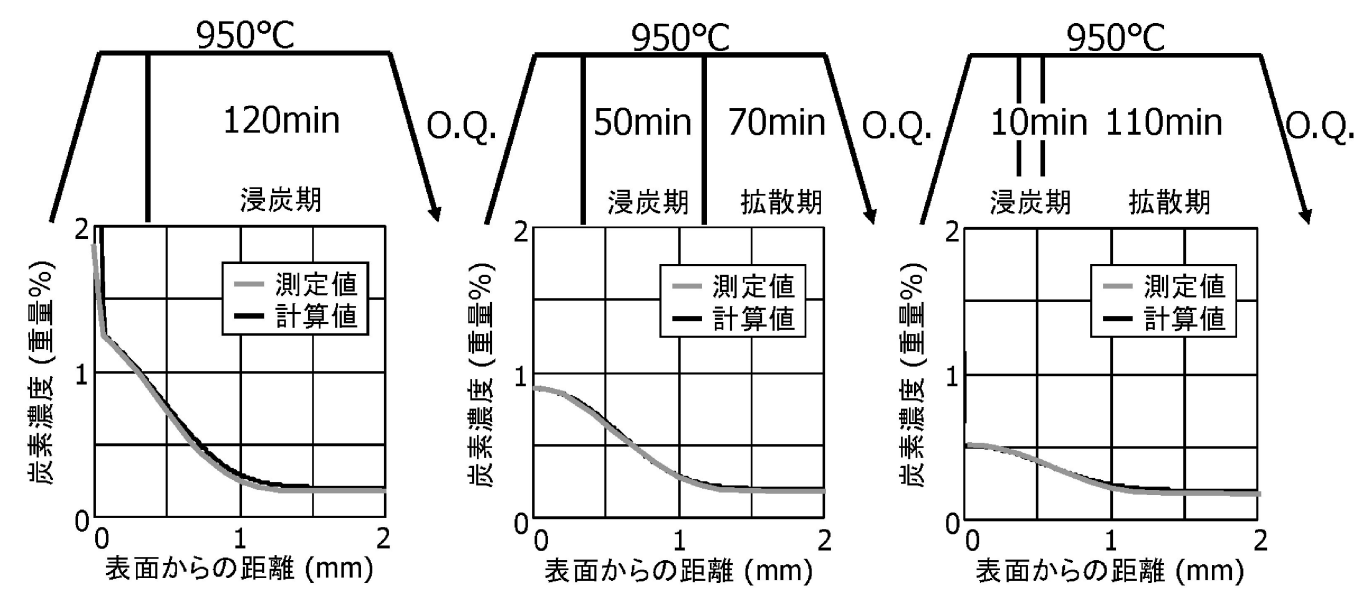

図 3 複数の浸炭条件による SCr420の炭素濃度分布の計算值と実測值の比較. 


\section{3. エッジ部過剩浸炭の生成機構}

本章では, 真空浸炭のもう一つの短所であるエッジ部の過 剰浸炭に関して述べる. 第 2 章で紹介した真空浸炭に抢け る平面に対する炭素濃度分布予測手法を応用し，エッジを有 する試験片を用いた実験結果と比較することで真空浸炭時の エッジ部過剰浸炭の原因を解明している ${ }^{(12)}$.

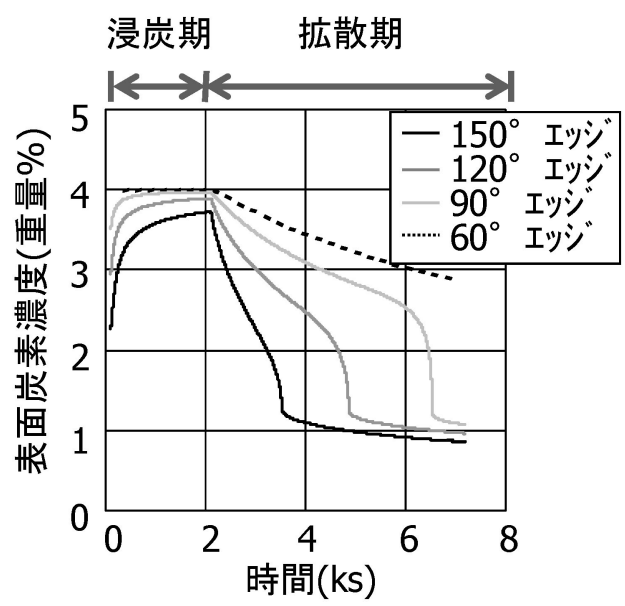

図 4 エッジ部表面炭素濃度の時間変化予測.

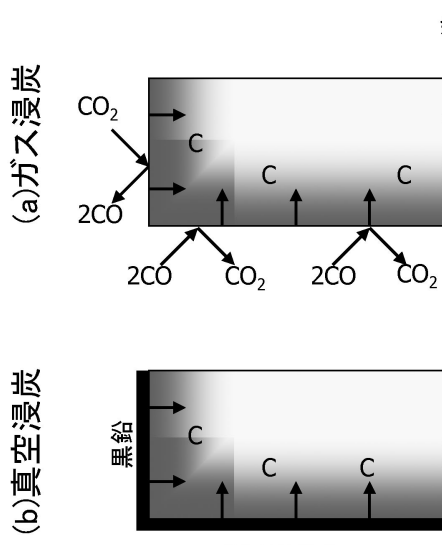

【浸炭期】
余唾炭素の脱炭

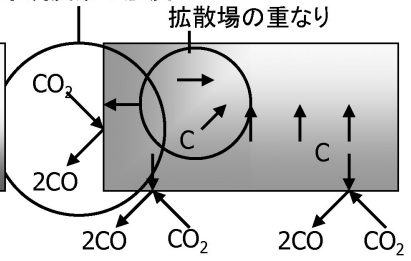

余剰炭素の残留

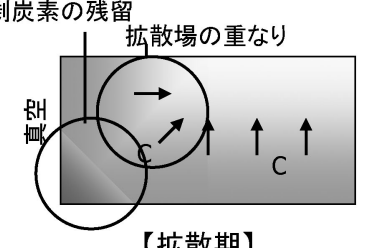

図 5 エッジ部の過剰浸炭生成機構の概略図.
図 4 にシミュレーションを用いて求めた真空浸炭材のエッ ジ先端の炭素濃度の時間変化を示す．浸炭期の表面炭素濃度 は形状が平面での機構と同様に黒鉛と平衡する值となり, エ ッジ角に対する依存性は小さい。しかし，拡散期にはエッジ 角度が鋭くなるに従い炭素濃度の低下が遅く，拡散期終了時 の炭素濃度が高くなっているのが分かる．このエッジ部過㮃 浸炭は，図 5 の概略図に示されるように，真空浸炭に必須な 拡散期に拈いてエッジ部では両辺からの炭素拡散場の重なり が発生し, 表面炭素濃度の低下が平面部よりも遅くなってい るため起こっている. 一方, ガス浸炭では表面炭素濃度が䨌 囲気との平衡から決定されるために起こらない.

\section{4. 真空浸炭材の合金設計}

真空浸炭時のエッジ部の過剰浸炭を克服するための対策と して, 浸炭条件を最適化(例えば平面部の表面炭素濃度を低 下させる方向に変更) が挙げられる ${ }^{(13)}$ が，歯車の平面部であ る歯面部においては強度低下が懸念されるため，本方策には 限界がある。本章では，エッジ部過剰浸炭とその疲労強度に 及ぼす合金元素の影響に関する研究事例(14)をはじめ，エッ ジ部の過剒浸炭を克服する合金設計ついて紹介する。

図 6 に $\mathrm{Si}-\mathrm{Cr}$ 変化させた 3 鋼種の $\mathrm{Fe}-\mathrm{C}$ 系状態図を，図 7 にエッジ部の炭素濃度分布計算結果を, 図 8 には代表として エッジ角度 $60^{\circ}$ を有する試験片の組織観察結果を示す。ちな みに，浸炭処理は平面部の表面炭素濃度が $0.75 \%$ となるよう に鋼材成分に応じて条件を変化させている．JIS-SCr420 相 当材である低 $\mathrm{Si}$-高 $\mathrm{Cr}$ 鋼では，エッジ角度が鋭くなるに従 い表面炭素濃度が高くなり，鋭角部では炭素の過剰導入によ り炭化物が生成している，一方，高 $\mathrm{Si}$-低 $\mathrm{Cr}$ 鋼では，表面 炭素濃度のエッジ角度依存性が小さく，鋭角部に拈いても炭 化物が生成しないことが分かる. 図 9 に示すように, SCr420の場合，エッジ角度の鋭角化に伴い，炭素の過剰導 入により生成した炭化物量が多くなるため強度低下を招く. したがって，エッジ部に抢いても高強度を得るためには，工 ッジ部の炭化物生成量を減少させること, すなわち, Fe-C 系状態図上で浸炭期の導入される炭素量が少ない, 高 $\mathrm{Si}-$ 低 $\mathrm{Cr}$ 系の合金設計が有効である. (a) $0.19 \mathrm{Si}-1.13 \mathrm{Cr}$ (JIS SCr420)

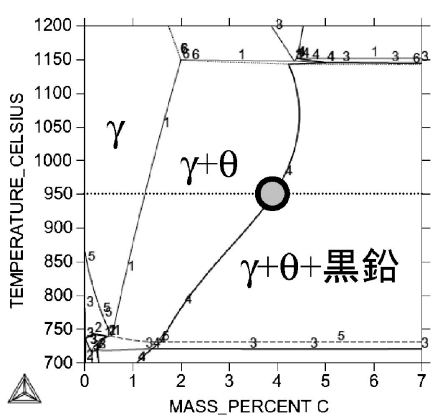

(b) $0.79 \mathrm{Si}-0.60 \mathrm{Cr}$

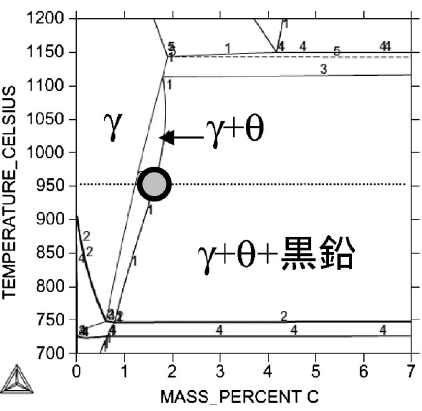

(c) $1.16 \mathrm{Si}-0.50 \mathrm{Cr}$

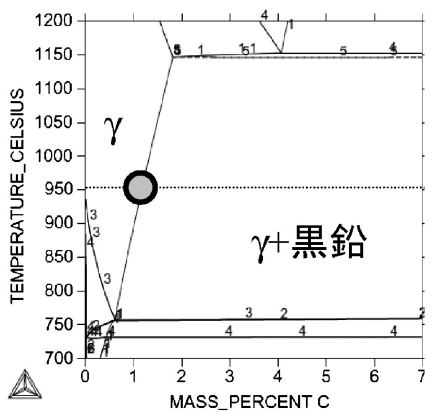

図 6 各鋼種の $\mathrm{Fe}-\mathrm{C}$ 系計算状態図. 


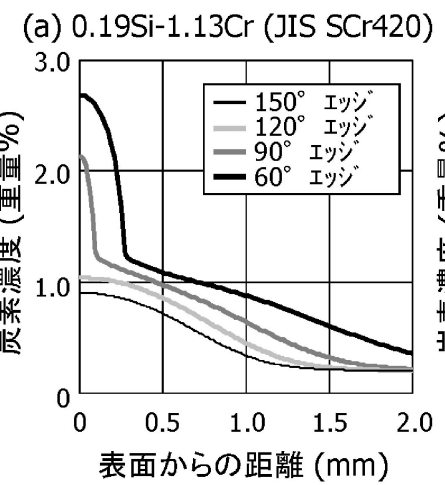

(b) $0.79 \mathrm{Si}-0.60 \mathrm{Cr}$

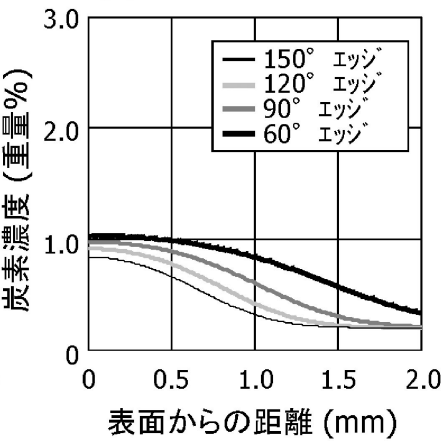

(c) $1.16 \mathrm{Si}-0.50 \mathrm{Cr}$

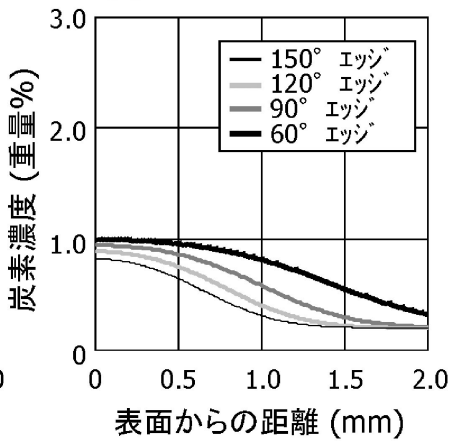

図 7 各鋼種のエッジ部の炭素濃度分布予測.

(a) $0.19 \mathrm{Si}-1.13 \mathrm{Cr}$ (JIS SCr420相当材)

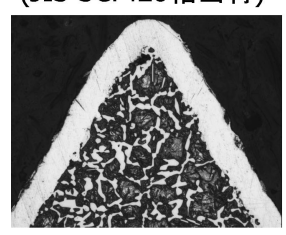

(b) $0.79 \mathrm{Si}-0.60 \mathrm{Cr}$

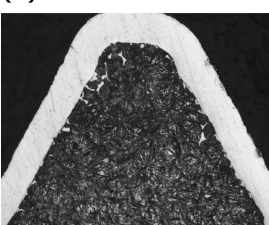

(c) $1.16 \mathrm{Si}-0.50 \mathrm{Cr}$

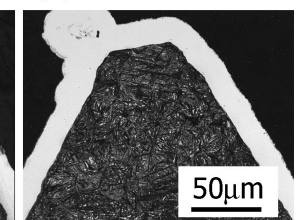

図 8 エッジ角度 $60^{\circ}$ の組織比較.

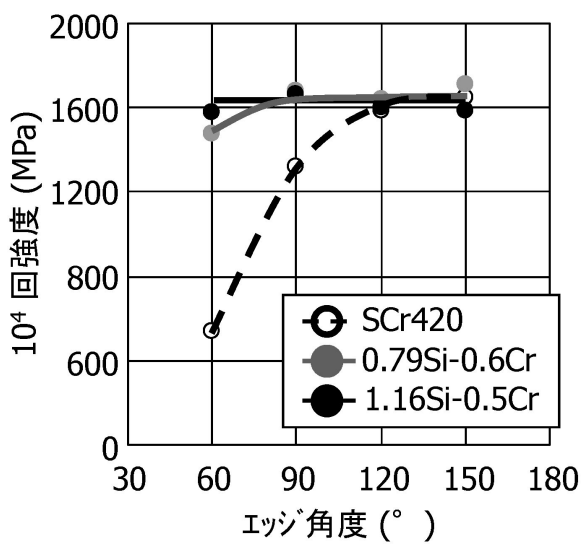

図 9 疲労強度とエッジ部角度の関係.

\section{5.おわりに}

真空浸炭の基礎として, 真空浸炭中の炭素侵入機構ならび にエッジ過㮃浸炭生成機構の概要をはじめ, 熱力学計算を利 用した炭素濃度分布予測技術と真空浸炭材の合金設計につい て解説した.これらの研究成果により, 真空浸炭シミュレー ションの実用化(浸炭くん) (11)ならびにエッジ過剩浸炭抑制 鋼の開発 (DEG シリーズ) (15)をはじめ, 高濃度浸炭やマイル ド浸炭 ${ }^{(16)}$, 真空浸炭窒化などの応用開発も盛んに行われ, 真空浸炭を活用した技術開発が活発化してきている.

また，近年，高温浸炭が容易な浸炭炉をはじめ，超小バッ

チ生産, 在庫低減,インライン化などのさらなる生産性の向 上を志向したスリムバッチ真空浸炭炉(17)の実用化が加速し て抢り，熱処理設備の革新も同時に進んでいる.

これらを背景に, 今後, 真空浸炭の普及はますます拡大す るものと予想される．そのため，材料技術，生産技術，熱処 理設備技術の連携はもちろんのこと，今回紹介したような熱 力学計算を活用した鋼材設計や組織予測は, 材料開発の効率 化の観点からも大変重要になると考元られる. そして, 真空 浸炭を活用した革新的な技術・商品が産み出されていくこと を大いに期待する.

\section{文献}

（1）杉山道生 : 熱処理, 37 (1997), 154.

(2) 町 哲司: 熱処理, 45 (2005), 80.

（3）下里吉計 : 工業加熱，39(2002), 21

(4) 門野 徹 : 工業加熱, 39(2002), 29.

（5）奥宮正洋, 新美 格, 恒川芳樹, 門谷政幸 : 第31回日本熱処 理技術協会講演大会講演概要集，(1990), 29.

（6）井上洋介, 井上吉弘 : 第58回日本熱処理技術協会講演大会講 演概要集, (2004), 1.

（7）河田一喜: 熱処理, 44(2004), 289.

(8) K. D. Jones and G. Krauss: Heat Treat., 79(1980), 188.

（9）森田敏之, 羽生田智紀 : 鉄と鋼, 92(2006), 268-273.

（10）森田敏之, 井上幸一郎, 羽生田智紀 : 電気製鋼, 77 (2006), 59.

(11) 電気製鋼, 79(2008), 91-93.

（12）森田敏之, 松村康志, 梅本 実：電気製鋼, 79(2008), 15-23.

(13) 森田敏之，梅本 実 : 鉄々鋼, 96 (2010), 400-405.

（14）森田敏之，松村康志：電気製鋼，81(2010), 109-116.

（15）電気製鋼, 79 (2008), 83-85.

（16）笠井大介, 大林巧治, 岡田一晃 : 熱処理, 57 (2017), 116-119.

（17）電気製鋼，84(2013)，61-66.

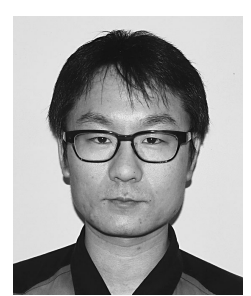

石倉亮平

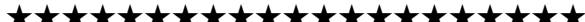
2005年 福井大学大学院工学研究科機械工学専攻修 土課程修了

2005年 4 月- 大同特殊鋼株式会社入社

2017年 4 月- 現職

専門分野：材料強度，表面処理技術

(9自動車構造用鋼の開発と応用に従事.トランスミッ ション部品用の鋼材・熱処理・表面処理技術開発を中 心に活動.

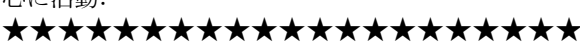

